Bangladesh J. Plant Taxon. 16(2): 151-156, 2009 (December)

(C) 2009 Bangladesh Association of Plant Taxonomists

\title{
CYTOGENETICAL ANALYSIS OF 12 TAXA OF GENISTA L. (FABACEAE) FROM TURKEY
}

\author{
Esra Martin ${ }^{1}$, Muhittin Dinc ${ }^{2}$, Ahmet Duran ${ }^{2}$, Bekir Dogan ${ }^{3}$ and Erdogan E. Hakki ${ }^{4}$ \\ Department of Biology, Nigde University, Nigde 51100, Turkey. \\ Keywords: Genista; Leguminosae; Chromosome number; Karyotype; Turkey.
}

\begin{abstract}
In this study, cytogenetical analyses of 12 taxa belonging to the genus Genista L. and grown naturally in Turkey were conducted. These taxa include G. acanthoclada, G. albida, G. anatolica, G. aucheri, G. burdurensis, G. carinalis, G. involucrata, G. januensis subsp. lydia, G. sandrasica, G. sessilifolia, G. tinctoria and G. vuralii. Chromosome numbers of all the taxa, except G. tinctoria, are introduced to the scientific community for the first time. Somatic metaphase chromosomes of the genus were determined as $2 \mathrm{n}=18,36,46,48,52,72$ and 144 . Polyploidy was observed in the cells of G. albida $(2 \mathrm{n}=18,2 \mathrm{n}=4 \mathrm{x}=36)$, G. tinctoria $(2 \mathrm{n}=$ $36,48,2 \mathrm{n}=4 \mathrm{x}=96)$, G. januensis subsp. lydia $(2 \mathrm{n}=46,2 \mathrm{n}=4 \mathrm{x}=92)$, $G$. burdurensis and G. sessilifolia $(2 \mathrm{n}=48,2 \mathrm{n}=4 \mathrm{x}=96)$. Somatic chromosomes of the $G$. sandrasica are very small, thus exact ploidy level of polyploidy was not determined. Karyotype analysis of $G$. albida and G. involucrata were performed via an Image Analysis System.
\end{abstract}

\section{Introduction}

Fabaceae (Leguminosae) is a large family represented by 650 genera and 18,000 species in the world (Kass and Wink, 1997). Except for Antarctica, taxa of Fabaceae may be found from herbaceous to shrubby forms in all continents. Fabaceae in Anatolia consisted of 974 species belonging to 69 genera (Davis et al., 1988) of Mimosoideae, Caesalpinioideae and Papilionoideae subfamilies. The genus Genista L. falls under the subfamily Papilionoideae which is made up of about 90 species in the world (Hickey and King, 1997; Duran and Dural, 2003).

Genista is distributed in the phytogeographic regions of Mediterranean and the related European, North African and West Asian territories (Hickey and King, 1997). It is widely accepted as a genus with Mediterranean origin. All of its species are perennial shrubby and short woody forms. In Turkey, the genus is specifically prevalent at the Mediterranean phytogeographic region, but is also pervasive at the transition zones of Mediteranean-Irano-Turanian as well as the Mediteranean-Euro-Siberian regions. Restricted distribution of Genista is also seen in the Eastern and South-Eastern Anatolia. Genista in Turkey is represented by 15 taxa, 14 species and one variety, and five species, namely G. aucheri, G. burdurensis, G. involucrata, G. sandrasica and G. vuralii are endemic to Turkey (Gibbs, 1970; Davis et al., 1988; Duran and Dural, 2003).

${ }_{1}$ Corresponding author. E-mail: esramartin@gmail.com

2 Department of Biology Education, Selcuk University, Konya 42090, Turkey.

${ }^{3}$ Department of Science Education, Selcuk University, Konya 42090, Turkey.

${ }^{4}$ Department of Field Crops, Selcuk University, Konya 42079, Turkey. 
Karyotypical knowledge needs to be used in conjunction with other sources of data to achieve a better understanding of the cytologic relationship of Genista taxa, leading to their natural classification. In this regard, the numbers of somatic chromosomes were determined in 12 taxa of Genista growing naturally in Turkey, and karyological attributes of selected taxa were evaluated for the first time.

\section{Materials and Methods}

Voucher specimens have been deposited at the herbarium of Selcuk University, Faculty of Education, Konya, Turkey (Table 1). Chromosome numbers and karyotypes were made on somatic metaphases using the squash technique. Root meristems from germinating seeds collected in the wild were used. Root tips were pretreated with $\alpha-$ monobromonaphthalene at $4^{\circ} \mathrm{C}$ for $16 \mathrm{~h}$. Root tips were fixed with Carnoy for $24 \mathrm{~h}$ at $4^{\circ} \mathrm{C}$. Before staining, the material was hydrolyzed with $1 \mathrm{~N} \mathrm{HCl}$ for 13 minutes at room

Table 1. Localities and other information on specimens of 12 Genista taxa studied.

\begin{tabular}{|c|c|}
\hline Taxon & Locality of voucher specimens \\
\hline G. acanthoclada DC. & $\begin{array}{l}\text { Mugla: Eski Kale road, } 900 \text { m, scrubby region, 23.07.2006, A. Duran } \\
7309 .\end{array}$ \\
\hline G. albida Willd. & $\begin{array}{l}\text { Burdur: Dirmil passage, preserved area, open spaces, } 1630 \mathrm{~m} \text {, } \\
\text { 25.07.2006, A. Duran } 7331 .\end{array}$ \\
\hline G. anatolica Boiss. & $\begin{array}{l}\text { Osmaniye: Amanos Mountains, Mitisin plateau, open Pinus nigra } \\
\text { forest, } 1350 \mathrm{~m}, 04.07 .2006, \mathrm{M} \text {. Dinc } 2702 .\end{array}$ \\
\hline G. aucheri Boiss. & $\begin{array}{l}\text { Sivas: Sivas-Zara interim, } 5 \mathrm{~km} \text { before Zara, steppe, } 1350 \mathrm{~m} \text {, } \\
\text { 26.07.2006, M. Dinc \& A. Duran } 2811 .\end{array}$ \\
\hline G. burdurensis P. Gibbs & $\begin{array}{l}\text { Burdur: Tefenni-Yesilova road, Karamanli exit, surrounding dam, } \\
\text { Quercus vacancy, } 1200 \text { m, 25.07.2006, A. Duran } 7336 \text {. }\end{array}$ \\
\hline G. carinalis Gris. & $\begin{array}{l}\text { Balıkesir: Edremit, from Kizılkecili village at Kaz Dagi, Gölcük } \\
\text { location, Pinus nigra and Quercus forest, } 400 \text { m, 22.07.2006, A. } \\
\text { Duran } 7302 \text {. }\end{array}$ \\
\hline G. involucrata Spach & $\begin{array}{l}\text { Sivas: Akdagmadeni-Y1ldizeli interval, Quercus distinction, } 25^{\text {th }} \mathrm{km} \text {, } \\
1275 \mathrm{~m}, 26.07 .2006 \text {, M. Dinc \& A. Duran } 2808 \text {. }\end{array}$ \\
\hline $\begin{array}{l}\text { G. januensis Viv. subsp. lydia } \\
\text { (Boiss.) Kit Tan \& Zieliński }\end{array}$ & $\begin{array}{l}\text { Osmaniye: Zorkun plateau, Kadirli peak, Cevizli region, Pinus nigra } \\
\text { forest, } 1500 \mathrm{~m}, 14.07 .2006, \mathrm{M} \text {. Dinc } 2786 \text {. }\end{array}$ \\
\hline G. sandrasica Hartwig \& Strid. & $\begin{array}{l}\text { Mugla: Köycegiz, Sandras Mountain, Pinus nigra forest, } 1700 \text { m, } \\
\text { 14.08.2007, M. Dinc \& S. Dogu } 3062 .\end{array}$ \\
\hline G. sessilifolia DC. & $\begin{array}{l}\text { Kirsehir: Sereflikochisar-Karaman road, } 5 \text { km before Karaman, step, } \\
1000 \text { m, 26.07.2006, M. Dinc \& A. Duran } 2810 .\end{array}$ \\
\hline G. tinctoria L. & $\begin{array}{l}\text { Erzincan: Refahiye İlic road }\left(7^{\text {th }} \mathrm{km}\right) \text {, steppe, } 1740 \mathrm{~m}, 28.07 .2006, \mathrm{M} \text {. } \\
\text { Dinc \& A. Duran } 2844 \text {. }\end{array}$ \\
\hline G. vuralii A. Duran \& H. Dural & $\begin{array}{l}\text { Cankırı: Ilgaz Mountain, Telekom transmitter vicinity, } 1900 \text { m, A. } \\
\text { Duran } 8143 .\end{array}$ \\
\hline
\end{tabular}


temperature. It was stained with $2 \%$ acetic orcein and mounted in $45 \%$ acetic acid. For all the counts, a minimum of ten plates from different individuals were examined and for each taxa only one population was studied. Permanent slides were made by using the standard liquid nitrogen method. Photographs were taken through BX50 Olympus microscope. The ideogram was prepared with measurements taken on enlarged micrographs of five well-spread metaphase plates. The karyotypes, the lengths of long and short arms, arm ratio, centromeric index, and relative chromosomal length were measured by Image Analysis System (Bs200Pro) loaded on a personal computer. At least five metaphase plates were measured for G. albida and G. involucrata. Chromosomes were classified using the nomenclature of Levan et al. (1964).

\section{Results and Discussion}

According to the cytogenetical data analyses of Genista, the somatical chromosome numbers of the studied taxa are highly divergent (ranging from $2 \mathrm{n}=18,36,46,48,72$ to 144) (Figs 1-14). The numbers of chromosomes were determined within G. albida and G. involucrata $(2 \mathrm{n}=18)$, G. albida and G. tinctoria $(2 \mathrm{n}=36)$, G. carinalis and $G$. januensis subsp. lydia $(2 \mathrm{n}=46)$, G. anatolica, G. burdurensis, G. sessilifolia, G. tinctoria and G. vuralii $(2 \mathrm{n}=48)$, G. acanthoclada $(2 \mathrm{n}=52)$, G. aucheri $(2 \mathrm{n}=72)$, and $G$. sandrasica $(2 \mathrm{n}$ $=144$ ). Although rare, a few cells revealed polyploidy in some of preparates (G. albida, G. burdurensis, G. januensis subsp. lydia, G. sandrasica, G. sessilifolia and Genista tinctoria). The numbers of chromosomes were determined in Genista albida $(2 \mathrm{n}=18,2 \mathrm{n}$ $=4 \mathrm{x}=36)$, G. tinctoria $(2 \mathrm{n}=36,48,2 \mathrm{n}=4 \mathrm{x}=96)$, G. januensis subsp. lydia $(2 \mathrm{n}=46$, $2 \mathrm{n}=4 \mathrm{x}=92)$, and $G$. burdurensis and $G$. sessilifolia $(2 \mathrm{n}=48,2 \mathrm{n}=4 \mathrm{x}=96)$. Tetraploid cells were determined in the same preparates where diploid chromosomes were counted. However, the somatic chromosome of the G. sandrasica is very small and it was difficult to determine the exact ploidy level of polyploidy.

Additionally, karyotype analyses of G. albida and G. involucrata were conducted by using an Image Analysis System (IAS) (Figs 15-16). The basic chromosome number of these species were $\mathrm{x}=9$. While chromosome morphology of G. albida was $9 \mathrm{~m}$, that of $G$. involucrata was determined as $8 \mathrm{~m}+1 \mathrm{sm}$. Total haploid chromosome size of G. albida was greater $(19.59 \mu \mathrm{m})$ when compared with $G$. involucrata $(18.08 \mu \mathrm{m})$. The length of chromosomes were measured between 1.55 and $3.19 \mu \mathrm{m}$ within the species G. albida, while it was 1.35-2.69 $\mu \mathrm{m}$ in G. involucrata. Chromosomal arm ratios differed in $G$. albida (1.13-1.65) from that of G. involucrata (1.09-1.94). From the cytological results, however, it was understood that, taxonomically, it is not appropriate to classify these two species since they have the same chromosome numbers and very similar karyotypes. Therefore, karyological features obtained in this study were not enough to classify these two species. 

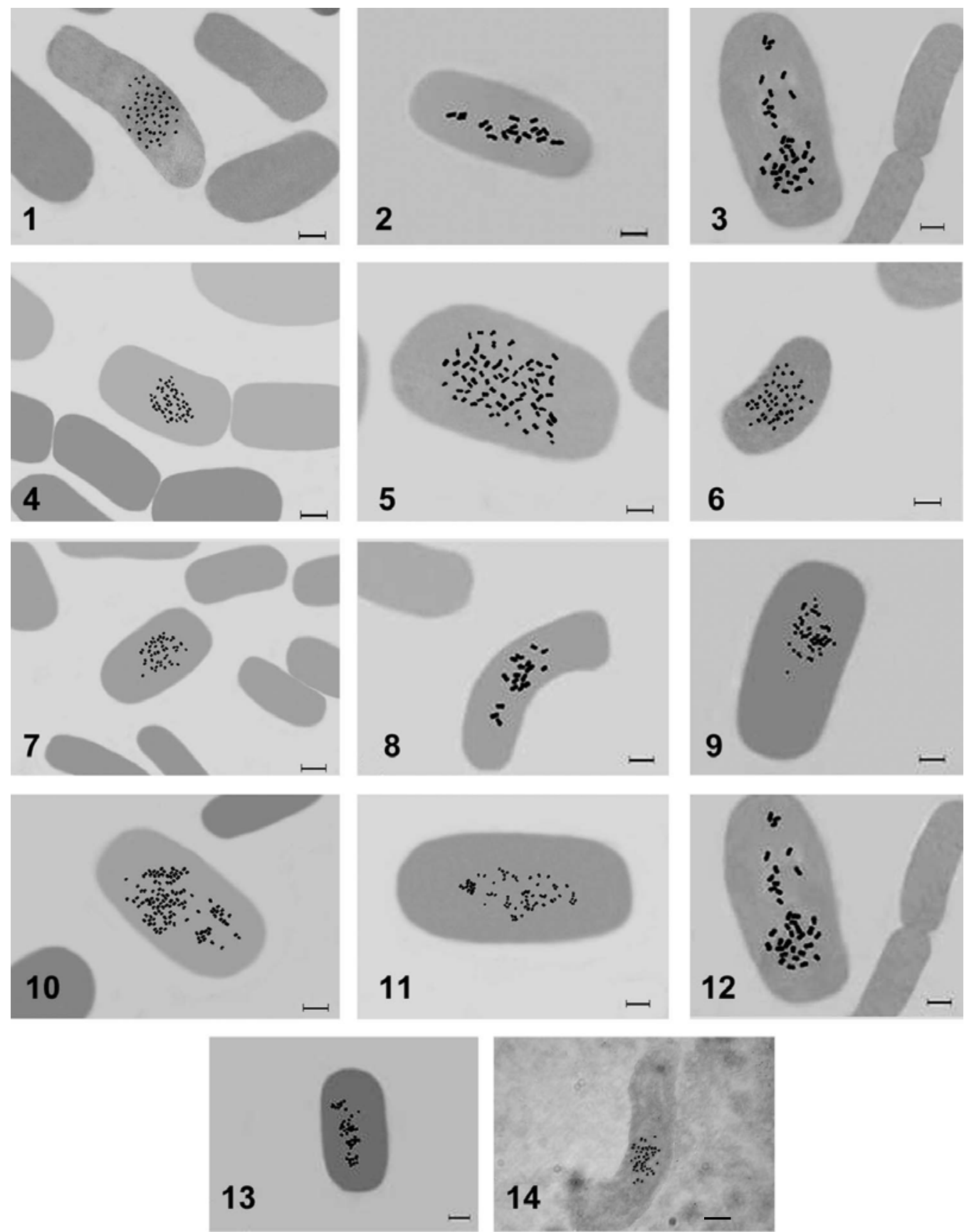

Figs 1-14. Metaphase chromosomes in study taxa. 1. G. acanthoclada $2 \mathrm{n}=52,2$. G. albida $2 \mathrm{n}=18,3$. G. albida $2 \mathrm{n}=36,4$. G. anatolica $2 \mathrm{n}=48,5$. G. aucheri $2 \mathrm{n}=72,6$. G. burdurensis $2 \mathrm{n}=48,7$. G. carinalis $2 \mathrm{n}=46,8$. G. involucrata $2 \mathrm{n}=18,9$. G. januensis subsp. lydia $2 \mathrm{n}=46,10$. G. sandrasica $2 \mathrm{n}$ $=144,11$. G. sessilifolia $2 \mathrm{n}=48,12$. G. tinctoria $2 \mathrm{n}=36,13$. G. tinctoria $2 \mathrm{n}=48,14$. G. vuralii $2 \mathrm{n}=48$. $($ Bars $=5 \mu \mathrm{m})$ 


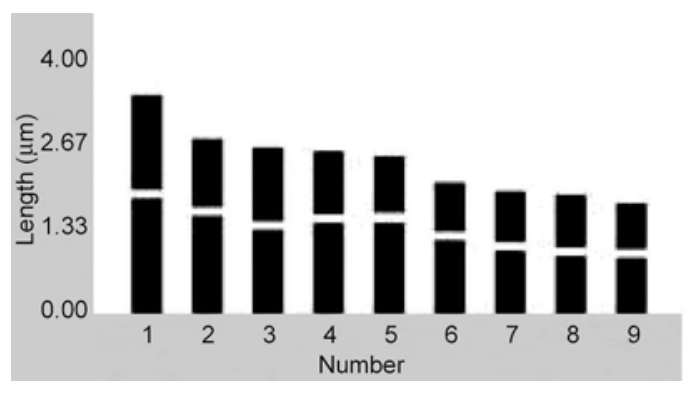

Fig. 15. Ideogram of Genista albida.

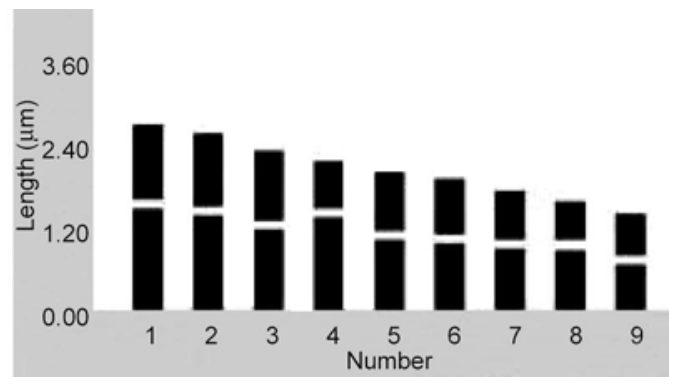

Fig. 16. Ideogram of Genista involucrata.

Karyological studies of Genista taxa distributed in the Balkan Peninsula were previously performed by Cubas et al. (1998) in order to resolve the genetic evolution of the taxa. In their study, they also used some species that are distributed in Anatolia and determined their chromosome numbers. These taxa included G. carpetana subsp. carpetana $(2 \mathrm{n}=40)$, G. cinerascens $(2 \mathrm{n}=24)$, G. micrantha $(2 n=36)$, G. mugronensis subsp. rigidissima $(2 \mathrm{n}=36)$, G. ramosissima $(2 \mathrm{n}=48)$, and G. tinctoria $(2 \mathrm{n}=48)$. In their study, novel aneuploid chromosome number for G. florida $(\mathrm{x}=23)$ as well as polyploidy $(2 \mathrm{n}=64)$ for $G$. tournefortii subsp. tournefortii were also determined. They also emphasized the need for further chromosomal data in order to clarify the cytological differentiation within the genus Genista. Two somatic chromosome numbers of $G$. tinctoria $(2 \mathrm{n}=36$ and 48$)$ are determined in the present study differing from Cubas et al. (1998). It is possible to consider G. tinctoria having different somatic chromosome numbers. These cytogenetic diversions may have an effect on the distinct occurrence of infraspecific variation.

The present study effectively determined the chromosome numbers and karyotypical characteristics of 12 Genista taxa that are naturally distributed in Turkey. This study expanded the range of chromosomal number in Genista and also recorded the karyological features of two Genista species.

\section{Acknowledgements}

Financial support received from the Scientific Research Coordination Center of Selcuk University (BAP-05401075) to conduct the study is gratefully acknowledged.

\section{References}

Davis, P.H., Mill, R.R. and Tan, K. (eds) 1988. Flora of Turkey and the East Aegean Islands. Vol. 3. (Suppl.). Edinburgh: Edinburgh Univ. Press, pp. 24-32.

Duran, A. and Dural, H. 2003. Genista vuralii (Fabaceae), a new species from Turkey. Annales Botanici Fennici 40: 113-116.

Cubas, P., Pardo, C., Sánchez-Mata, D. and Canto, P. 1998. Karyological and taxonomic notes on Genista L. (Papilionoideae, Leguminosae) from the Iberian Peninsula. Botanical Journal of the Linnean Society 128: $423-434$ 
Gibbs, P.E. 1970. Genista L. In: Davis, P.H. (ed.), Flora of Turkey and the East Aegean Islands. Vol. 3. Edinburgh: Edinburgh Univ. Press, pp. 24-32.

Hickey, M. and King, C. 1997. Common Families of Flowering Plants. Cambridge University Press, UK, pp. 1-197.

Kass, E. and Wink, M. 1997. Phylogenetic relationships in the Papilionoideae (Family Leguminosae) based on nucleotide sequences of cpDNA (rbcL) and ncDNA (ITS 1 and 2). Molecular Phylogenetics and Evolution 8: 65-88.

Levan, A., Fredga, K. and Sandberg, A.A. 1964. Nomenclature for centromeric position on chromosomes. Hereditas 52: 201-220.

(Manuscript received on 17 March 2009; revised on 1 June 2009) 